\title{
Quinoxalines and tetraketones for metal cations extraction
}

\author{
Ibrahim Bouabdallah, ${ }^{\mathrm{a}, *}$ Ismail Zidane, ${ }^{\mathrm{a}}$ Rachid Touzani, ${ }^{\mathrm{a}}$ Brahim Hacht, \\ and Abdelkrim Ramdani ${ }^{a}$ \\ ${ }^{a}$ Laboratoire de Chimie Organique Physique \\ ${ }^{b}$ Laboratoire de Spéciation et de Surveillance de la Pollution en Méditerranée,Département de \\ Chimie, Faculté des Sciences, Université Mohamed Premier, BP 524, Oujda, Maroc \\ E-mail: bouabib2002@yahoo.fr
}

\begin{abstract}
A variety of 2,3-bifunctionalized quinoxalines (3-8) have been prepared by the condensation of disubstituted tetraketones $(\mathbf{1 , 2})$ with substituted $o$-phenylenediamines. The liquid-liquid extraction behaviour of copper (II), lead (II) and cadmium (II) from aqueous solution has been investigated in dichloromethane solution using functionalised compounds (1-8). The extracted cation percentage was determined by atomic absorption spectrophotometry measurements. The effect of the R' substituents of the tautomeric quinoxaline forms was examined.
\end{abstract}

Keywords: Quinoxaline, tautomeric forms, tetraketone, extraction, copper (II), lead (II), cadmium (II)

\section{Introduction}

In modern times, the treatment of waste water constitutes a crucial part of most industrial processes. Efficient separation of metal ions by solvent extraction either from industrial wastes or from raw materials is gaining importance as the most common technique used. The literature is well documented with the use of $\beta$-diketones and quinoxalines as chelating ligands in solvent extraction. Previous studies ${ }^{1}$ were focussed on the extraction of lanthanoids by 1-phenyl-3isoheptyl-1,3-propanedione and $\beta$-diketones, which have been extensively used as extractants in the separation of metal ions. ${ }^{2,3}$ Also, quinoxaline derivatives are currently being studied as chemical chelants ${ }^{4,5}$ and have been employed extensively as analytical reagents in the determination of metal ions by liquid-liquid extraction. 5,6

In the present paper, we report studies on the effect of the $\mathrm{R}$ ' substituent in the tautomeric quinoxaline forms and the liquid-liquid extraction properties of tetraketone and quinoxaline derivatives with three metal ions $\mathrm{Cu}^{2+}, \mathrm{Pb}^{2+}$ and $\mathrm{Cd}^{2+}$. 


\section{Results and Discussion}

Quinoxaline derivatives $3-\mathbf{8}^{9-12}$ were prepared by the condensation of the corresponding tetraketones $1,2^{7,8}$ with cyclic diamines (ortho-phenylenediamine or 4-methyl or 4-nitro-orthophenylenediamine) in refluxing ethanol (Scheme 1).<smiles>[R]/C(=C/C(=O)C(=O)/C([R])=C/O)O[TlH]</smiles>

1,2

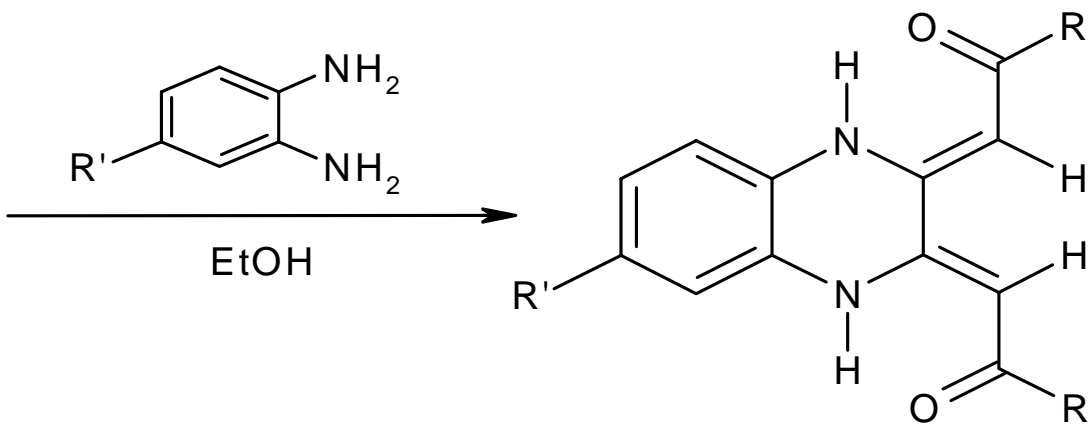

3-8

$$
\begin{aligned}
& 1: \mathrm{R}=\mathrm{C}_{6} \mathrm{H}_{5} \\
& \text { 3: } \mathrm{R}^{\prime}=\mathrm{H} \quad, \mathrm{R}=\mathrm{C}_{6} \mathrm{H}_{5} \quad ; \quad 6: \mathrm{R}^{\prime}=\mathrm{H} \quad, \mathrm{R}=\mathrm{CH}\left(\mathrm{CH}_{3}\right)_{2} \\
& \text { 2: } \mathrm{R}=\mathrm{CH}\left(\mathrm{CH}_{3}\right)_{2} \\
& \text { 4: } \mathrm{R}^{\prime}=\mathrm{CH}_{3}, \mathrm{R}=\mathrm{C}_{6} \mathrm{H}_{5} ; 7: \mathrm{R}^{\prime}=\mathrm{CH}_{3}, \mathrm{R}=\mathrm{CH}\left(\mathrm{CH}_{3}\right)_{2} \\
& 5: R^{\prime}=\mathrm{NO}_{2}, \mathrm{R}=\mathrm{C}_{6} \mathrm{H}_{5} ; 8: \mathrm{R}^{\prime}=\mathrm{NO}_{2}, \mathrm{R}=\mathrm{CH}\left(\mathrm{CH}_{3}\right)_{2}
\end{aligned}
$$

\section{Scheme 1}

It has been confirmed ${ }^{9}$ that the keto-enamine form $(\mathrm{C})$ is the preferred form for compound 3 (Scheme 2).<smiles>[R]C(=O)Cc1nc2ccc([R])cc2nc1CC([R])=O</smiles>

Scheme 2. Different tautomeric forms of quinoxaline derivatives

The proton NMR spectra of compounds 3-8, revealed signals at $5.69-6.65 \mathrm{ppm}$, corresponding to the vinylic protons, clearly excluding the imino-ketone form (A). In dissymmetrical quinoxalines 4,5,7,8 two peaks were observed (Table 1), however, in the symmetrical products 3, 6 one signal was observed in their ${ }^{1} \mathrm{H}-\mathrm{NMR}$ spectra. Moreover, the ${ }^{1} \mathrm{H}$ 
NMR of 4 - 8 not only revealed the absence of the methyl protons, but also the presence of the $\mathrm{N}-\mathrm{H}$ protons. Further, ${ }^{13} \mathrm{C}$ NMR spectra revealed signals at $188.82-205.62 \mathrm{ppm}$ corresponding to the $\mathrm{C}=\mathrm{O}$ groups, and the absence of the peaks corresponding to $\mathrm{C}-\mathrm{OH}$ (Table1). These results confirm the predominance of the keto-enamine form (C), not affected by the $\mathrm{R}^{\prime}$ substituents in the quinoxaline derivatives. On the other hand, when $\mathrm{R}^{\prime}$ is electron withdrawing, quinoxaline yield was the same in both $\mathbf{5}$ and $\mathbf{8}$ compounds. Therefore, the heterocyclisation was controlled by the nitro electro-attracting effect (Scheme 3). However, when $\mathrm{R}^{\prime}$ is electron donating the quinoxaline yields increased with the phenyl ring and decreased with the isopropyl moiety.
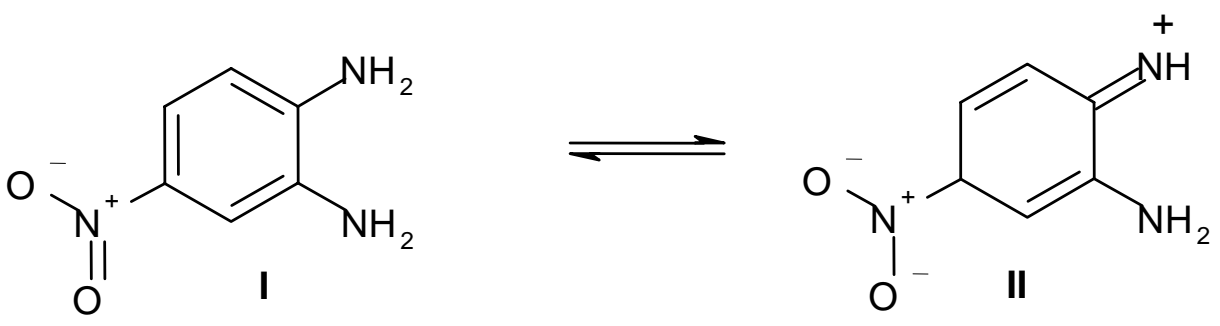

\section{Scheme 3}

Table 1. Comparative study between quinoxaline derivatives ${ }^{9-14}$

\begin{tabular}{cccccccc}
\hline$R$ & Compd. & $R^{\prime}$ & Yield & $T_{f}\left({ }^{\circ} \mathrm{C}\right)$ & $\delta=C-H(p p m)$ & $\Delta \delta=C-H(H z)$ & $\delta N-H(p p m)$ \\
\hline \multirow{4}{*}{$P h$} & $\mathbf{3}$ & $\mathrm{H}$ & 82 & 216 & 6.48 & --- & 15.00 \\
& $\mathbf{5}$ & $\mathrm{NO}_{2}$ & 43 & 178 & $6.58 / 6.65$ & 21.0 & $14.73 / 14.89$ \\
& $\mathbf{4}$ & $\mathrm{CH}_{3}$ & 88 & 180 & $6.56 / 6.57$ & 2.2 & $15.05 / 15.20$ \\
\hline \multirow{4}{*}{ Isop. } & $\mathbf{6}$ & $\mathbf{H}$ & 50 & 70 & 5.72 & --- & 14.81 \\
& $\mathbf{8}$ & $\mathrm{NO}_{2}$ & 41 & 150 & $5.82 / 5.86$ & 12.4 & $14.26 / 14.21$ \\
& 7 & $\mathrm{CH}_{3}$ & 64 & 98 & $5.69 / 5.71$ & 4.0 & $14.46 / 14.66$ \\
\hline
\end{tabular}

As shown in Table 1, the vinylic signals are very influenced by the nature of the $\mathrm{R}^{\prime}$ groups. The nitro group, a strong electron withdrawing group, provides a strong chemical displacement difference between the two vinylic protons $[5 . \Delta \delta(\mathrm{C}-\mathrm{H})=21.0 \mathrm{~Hz} ; \mathbf{8} . \Delta \delta(\mathrm{C}-\mathrm{H})=12.4 \mathrm{~Hz}]$, in comparison with the methyl group $[4 . \Delta \delta(\mathrm{C}-\mathrm{H})=2.2 \mathrm{~Hz} ; 7: \Delta \delta(\mathrm{C}-\mathrm{H})=4.0 \mathrm{~Hz}]$.

The results given in Table 2 correspond to the percentages (E\%) of extracted cations from solutions of the functionalised derivatives (1-8). The percentages of extraction of transition metal ions $\left(\mathrm{Cu}^{2+}, \mathrm{Pb}^{2+}, \mathrm{Cd}^{2+}\right)$ at $\mathrm{pH}=7$ and room temperature were calculated. ${ }^{13}$

Concerning tetraketone compounds $(1,2)$, the extractions are around $30 \%$ for $\mathrm{Cu}^{2+}$ and very low for both $\mathrm{Pb}^{2+}$ and $\mathrm{Cd}^{2+}$. These results show an extraction ability only with copper metal cation and no complexation toward lead and cadmium cations. Further, the stability provided by 
the aromatic ring in compound $\mathbf{1}$, had no effect on the percentage extraction in comparison with tetraketone $\mathbf{2}$. This result demonstrates that the complexation is controlled by acyclic geometries.

Table 2. Extraction percentages (E\%) of cations by tetraketone and quinoxaline derivatives

\begin{tabular}{ccccccccc}
\hline Metal Ion & $\mathbf{1}$ & $\mathbf{2}$ & $\mathbf{3}$ & $\mathbf{4}$ & $\mathbf{5}$ & $\mathbf{6}$ & $\mathbf{7}$ & $\mathbf{8}$ \\
\hline $\mathrm{Cu}^{2+}$ & 30 & 32 & 22 & 18 & 19 & 16 & 16 & 21 \\
$\mathrm{~Pb}^{2+}$ & 00 & 02 & 09 & 08 & 12 & 13 & 08 & 11 \\
$\mathrm{Cd}^{2+}$ & 00 & 01 & 01 & 04 & 01 & 00 & 00 & 00 \\
\hline
\end{tabular}

Moreover, quinoxaline compounds (3-8) have no affinity for $\mathrm{Cd}^{2+}$ but, they extract copper to approximately twice the extent of the lead cation. The dissymmetric quinoxalines $(4,5,7,8)$ have similar extraction percentages as the symmetric compounds $(3,6)$. These results are probably due to the electrostatic interaction between the cations and the cavity formed by the keto-enamine forms.

In conclusion, we have demonstrated that the keto-enamine forms are not affected by the $\mathrm{R}^{\prime}$ moieties in the quinoxaline derivatives. Under these conditions $\left(25^{\circ} \mathrm{C}, \mathrm{pH}=7\right), \mathrm{Cu}$ (II), $\mathrm{Cd}$ (II) and $\mathrm{Pb}$ (II) are poorly extracted from aqueous solution by quinoxaline and tetraketone derivatives. Studies on this matter are currently in progress, especially as to the influences of ionic strength, $\mathrm{pH}$ and metal or ligand concentrations in extraction percentages.

\section{Experimental Section}

General Procedures. The extraction of metals was investigated using nitrate salts. The organic solutions were made by dissolving a weighed amount of the compound in dichloromethane. Liquid-liquid extraction experiments were carried out in a flask by shaking for $2 \mathrm{~h}$ in a thermostated bath. The temperature remained constant during all the experiments at $25^{\circ} \mathrm{C}$ and at pH 7 measured by $\mathrm{pH}$-meter. $25 \mathrm{~mL}$ of aqueous phase containing metal salt $\left(7.10^{-5} \mathrm{M}\right)$ and 25 $\mathrm{mL}$ of organic phase containing the quinoxaline or tetraketone derivatives $\left(7.10^{-5} \mathrm{M}\right)$

The aqueous phase was separated and analyzed by atomic absorption spectrometry with an air-acetylene flame. The measurements were carried out using standard conditions for calibration.

\section{References and notes}

1. Shigeto, N.; Shuichi, T.; Kenichi, A. Anal. Sc. 2002, March, 18, 319.

2. Alfonso, O.; Aurora, M.; Francisco, Z.; Patricion, P. Microchim. Acta 2002, 140, 201.

3. Roqai, M. C.; Grandmont, G. J. G.; Brunette, J. P. Analysis 1998, $26,74$.

4. Alaa, S. A., Specrtochim. Acta Part A. 2002, 58, 1831. 
5. Tomaszewski, L.; Ding, Z.; Fermin, D. J.; Cacote, H. M.; Pereira, C. M.; Silva, F. ; Girault, H. H. J. Electroanal. Chem.1998, 453, 171.

6. Asuero, A. G.; Navas, M. J. ; Jimenez-Trillo, J. L., Microchem. Journal. 1985, 31, 81.

7. Rolf, W. S.; Norbert, L.; Bernhard, D.; Dictmar, S. ; Markus, T. Chem. Eur. J. 1998, 4, 7, 1035.

8. Bouabdallah, I.; Ramdani, A.; Zidane, I.; Touzani, R.; Malek, F. ; El Kodadi, M. Molbank 2003, M 345.

9. Touzani, R.; Ben-Hadda, T.; El Kadiri, S.; Ramdani, A.; Maury, O.; Le Bozec, H. ; Toupet, L.; Dixneuf, P. H.; New J. Chem. 2001, 25, 391.

10. Bouabdallah, I.; Ramdani, A.; Zidane, I.; Touzani, R.; Malek, F. ; El Kodadi, M. Molbank 2003, M 346.

11. Waring, M. J.; Ben-Hadda, T.; Kotchevar, A. T. ; Ramdani, A.; Touzani, R.; Elkadiri, S.; Hakkou, A.; Bouakka, M.; Ellis,T.; Molecules 2002, 7, 41.

12. Bouabdallah, I.; Ramdani, A.; Zidane, I.; Touzani, R.; Malek, F. ; El Kodadi, M. Molbank 2004, M 383-M385.

13. Radi, S.; Ramdani, A. ; Lekchiri, Y.; Morcellet, M.; Crini, G. ; Janus, L. Tetrahedron 2004, $60,939$. 